\title{
Kearbitreran Bahasa Arab dan Urgensi Mempelajarinya dalam Pandangan Linguis Arab Klasik
}

\author{
Fathi Hidayah \\ Institut Agama Islam Ibrahimy Banyuwangi \\ hidavahfathi@gmail.com
}

\begin{abstract}
Abstrak: Arabic is one of the most complicated languages in terms of grammar. The difference in the mention of verbs for each subject gives philosophically bidden meanings. The uniqueness of the Arabic language is much described by classical scholars, who of course cannot be separated from its philosophy. Not only mention Arabic as the language of heaven, but there are many descriptions about it. These classical scholars in the book. Abu Mansur Ats-tsa'laby, who mention the virtues of Arabic are Umar bin Khatab, Imam Shafi'i, Al-Jahiz to Ibn Junni. In addition, Arabic lexicologists also gave their descriptions of the virtues of the Arabic language.
\end{abstract}

Keyword: Arabic, classical scholars, Arabic lexicologists

\section{Pendahuluan}

Bahasa adalah bagian dari produk budaya manusia. Bahasa akan tumbuh dan berkembang sesuai dengan tumbuh dan berkembangnya budaya manusia. Dengan kata lain, bahasa akan tumbuh seiring dengan berkembangnya kemampuan manusia dalam memproduksi karya-karya besar berupa sains, teknologi, seni dan bidang-bidang lainnya. Semuanya tidak terlepas dari peran bahasa yang digunakannya.

Bahasa, dengan demikian adalah alat yang dapat menembus berbagai dimensi dalam budaya manusia. Oleh karena itu, bahasa pun tentunya juga bisa dikaji dari berbagai sudut pandang. Keterbukaan sifat bahasa yang semacam inilah kemudian melahirkan berbagai definisi tentang bahasa. Salah satunya adalah pendapat Al Khuli yang menyebutkan bahwa bahasa adalah system suara yang terdiri atas symbol-simbol arbiter (manasuka) yang digunakan oleh 
seseorang atau sekelompok orang untuk bertukar pikiran atau berbagi rasa ${ }^{1}$. Selain itu, masih banyak lagi definisi-definisi tentang bahasa yang diungkapakan oleh banyak ahli.

Dari berbagai definisi tentang bahasa, dapat disimpulkan bahwa hakikat bahasa adalah sebuah system, arbiter (manasuka), ujaran, simbol, manusiawi (diproduksi dan digunakan oleh manusia), alat komunikasi dan bahasa mengacu pada objek baik bahasa itu sendiri atau sesuatu diluar bahasa itu ${ }^{2}$.

Jika karakteristik bahasa tersebut bersifat universal, maka semua bahasa yang ada di dunia ini akan memiliki karakteristik tersebut, begitu juga dengan bahasa Arab. Di lihat dari segi penggunanya, bahasa Arab merupakan bahasa yang dituturkan oleh lebih dari 200 juta umat manusia di dunia. Bahasa ini secara resmi digunakan oleh kurang lebih 20 negara $^{3}$.

Bahasa Arab juga merupakan salah satu bahasa yang mempunyai konsep pemeliharaan yang kuat semenjak terbentuknya. Berakar dari rumpun bahasa Semit yang berujung pada peradaban Babilonia dan Asyiria jauh sebelum datangnya Islam ${ }^{4}$. Bahasa-bahasa Semit yang lain termasuk Akkadian yang dituturkan oleh masyarakat Babilonia dan Assyria yang sekarang sudah punah, bahasa Aramiki (Aramaic) yang dituturkan oleh penduduk tanah suci di masa Nabi Isa a.s yang kini masih dipakai oleh penduduk beberapa kampong di Syiria. Hebrew/Ibrani (Yahudi) yang saat ini dituturkan di Israel. Dari kesemua itu, bahasa Arab-lah yang sampai saat ini paling banyak digunakan di tempat kelahirannya tersebut ${ }^{5}$.

Keistimewaan bahasa Arab yang paling besar adalah bahwa Al Qur'an sebagai kitab suci umat Islam diturunkan dalam bahasa Arab. Dengan demikian, bahasa Arab akan senantiasa digunakan, dipelajari dan dikembangkan selama Islam masih ada di muka bumi ini. Dan karena bahasa Arab merupakan bahasa kitab suci dan bahasa tuntunan agama umat Islam seluruh dunia, maka bahasa

1 Al-Khuli, Muhammad Ali.1982. Asaalib Tadriis al Lugab al 'Arabiyyah. Riyadh: Mamlakah al 'Arabiyyah as Su'udiyyah, hal.148. lihat Finochiaro (1974:14) menyebutkan bahwa bahasa adalah system arbiter (manasuka) yang terdiri atas symbol-simbol suara yang digunakan oleh manusia dalam mentransfer budaya kepada yang lainnya atau mereka yang telah mempelajari budaya dalam berkomunikasi. Hal.9-10.

2 .Hermawan, Acep. 2011. Metodologi Pembelajaran Bahasa Arab. Bandung: PT. Remaja Rosdakarya.

3. Arsyad, Azhar. 2010. Bahasa Arab dan Metode Pengajarannya; Beberrapa Pokok Pikiran. Yogyakarta:Pustaka Pelajar. Hal.1.

4. Al Yasiri, Ali Mazhar. 2003. Al Fiker an Nab\}wi Inda al 'Arab Us\}u>lubu wa Mana>bijubu. Beirut: Dar al 'Arabiyyah Lil Mausu'ah. Hal 5. Studies. Hal.1.

5 .Ghazzawi, Sabah. 1992. The Arabic Language. Washington D.C:Center for Contemporary Arab 
Arab merupakan bahasa yang paling besar signifikansinya bagi ratusan juta umat Muslim di dunia, baik yang berkebangsaan Arab atau bukan ${ }^{6}$.

Selain bahasa Al Qur'an, bahasa Arab juga merupakan bahasa hadis, bahasa yang saat ini menjadi salah satu kekuatan ekonomi dunia, mau tidak mau apabila kita ingin berperan dalam kancah global tidak akan mungkin tanpa bersinggungan dengan dunia Arab yang berarti juga mempelajari bahasanya. Oleh karena itu, saat ini bahasa Arab merupakan bahasa yang peminatnya cukup besar di Barat, banyak universitas-universitas terkemuka yang membuka studi tentang Arab Studies atau Middle East Studies.

Sedemikian banyak keutamaan dan keistimewaan bahasa Arab ini tentunya bukan merupakan sesuatu yang baru saja kita ketahui saat ini. Jauh sebelum bahasa Arab berkembang pesat seperti saat ini, para ulama telah menganjurkan untuk mempelajari bahasa Arab. Bagaimana pandangan mereka tentang bahasa Arab dan urgensi mempelajarinya?.

\section{Pembahasan}

\section{Pendapat-Pendapat Ulama tentang Keutamaan Bahasa Arab}

Dalam pembukaan buku "Figh al Lugah al 'Arabiyyah" Abu Mansur Al Tsa'laby mengungkapkan bahwa "Siapa yang mencintai Allah SWT, pasti mencintai Rasulullah SAW. Dan orang yang mencintai Rasul yang orang Arab, pasti akan mencintai bangsa Arab. Dan orang yang mencintai bangsa Arab pasti mencintai bahasa Arab, dan orang yang mencintai bahasa Arab pasti akan menjaganya, akan konsisten terhadapnya, akan mencurahkan semangat kepadanya. Dan orang yang ditunjukkan oleh Allah kepada Islam dan melapangkan dadanya untuk iman, dan mendekati kebaikan, yakin bahwa Muhammad SAW adalah rasul terbaik, dan bangsa Arab adalah umat terbaik, dan bahasa Arab adalah bahasa dan ucapan terbaik. Dan jika memahaminya akan mendapatkan kemakmuran beragama, jika bahasa Arab adalah sarana ilmu, dan kuncinya memahami agama, dan menjadi sebab kesuksesan kehidupan dan kematian"'.

Dari pendapat tersebut dapat diketahui bagaimana kedudukan bahasa Arab serta keutamaan mempelajarinya. Tentu saja hal ini bukan hanya karena bahasa Arab adalah bahasa Al Qur'an dan bahasa umat Islam, tetapi jauh lebih dari konteks bahasa tersebut, tetapi juga konten bahasa Arab yang sangat besar untuk dieksplorasi. Tak heran jika bahasa Arab dianggap sebagai the supreme

\footnotetext{
${ }^{6}$. Azhar, Arsyad, op.cit. hal.1.

7. Amin, Usman. 1965. Falsafah al Lugah al Arabiyyah. Kairo: Dar al Masriyah li Ta'lif wa Tarjamah.
} Hal.22. 
standard of linguistics excellence and beauty ${ }^{8}$ oleh para pengamat bahasa di Barat. Selanjutnya adalah pandangan-pandangan ulama Muslim sendiri tentang bahasa Arab:

\section{a. Umar bin Khathab}

Dalam pandangan Umar bin Khathab mempelajari bahasa Arab tidak hanya sekedar mempelajari bahasa pada umumnya, akan tetapi bahasa Arab juga menautkan pembelajarnya pada pokok-pokok keluhuran, nilai dan moral.

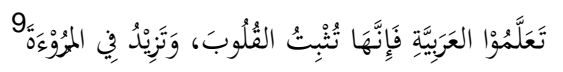

"Pelajarilah bahasa Arab, karena sesungguhnya bahasa itu (Arab) mengukuhkan akal dan menambah kehormatan"

Mengingat, bahasa Arab dalah bahasa Al Qur'an, jadi, semakin orang tahu dan paham akan bahasa Arab, maka secara otomatis ia akan lebih paham tentang kaidah agama Islam dalam al Qur'an dan hadis. Dan apabila seseorang telah paham Al Qur'an dan hadis, maka dengan sendirinya ia akan menjaga dirinya dari segala sesuatu yang telah ditentukan di dalamnya, dari segi perintah, larangan yang dengan sendirinya akan berpengaruh dalam keteguhan hatinya. Akalnya juga akan senantiasa berpikir dan berpikir dalam mengeksplorasi ilmu Allah yang dituangkan dalam Al Qur'an. Sebagaimana dijelaskan sebelumnya bahwa bahasa adalah kunci pengetahuan.

Belajar bahasa Arab akan menambah kehormatan seseorang. Penjelasannya adalah, penggunaan bahasa Arab dalam keseharian seseorang, baik untuk penggunaan aktif (dialog) ataupun pasif, merupakan "kewajiban agama". Hal ini merujuk pada kewajiban untuk mempelajari Islam lewat kitab suci yang berbahasa $\mathrm{Arab}^{10}$.

Secara garis besar pendapat Umar bin Khathab dalam mempelajari bahasa Arab berlatarbelakang motif agama. Hal ini tentu saja didasarkan pada konteks zaman dimana Umar hidup pada saat itu. Pada masa kekhalifahannya, Islam mulai menyebar hingga ke Persia di Asia Tengah, bahkan hampir sampai ke wilayah Himalaya, di Eropa Islam menyentuh hingga wilayah Bizantium dan di benua Afrika menyebar hingga ke Mesir ${ }^{11}$. Umar juga memperkenalkan sistem administrasi kenegaraan dalam mengelola Dar Islam yang telah beliau ciptakan tersebu ${ }^{12}$ t. Artinya, Umar mengingikan adanya sentralisasi komando yang secara

8 . Arsyad, Azhar. Op.cit. hal 6.

9. Awadh, Ahmad Abduhu. 2000. Fi Fadlli al Lugah al Arabiyyah, ta'liman wa tabdiithan wa iltizaaman. Kairo: Markaza al Kitab li an Nasyr. Hal 75.

${ }^{10} \mathrm{Ibid}$.

11 .Amstrong, Karen. 2003. Islam Sejarah Singkat. Yogyakarta: Penerbit Jendela. Hal 36-37.

12. Yatim, Badri. 1993. Sejarah Peradaban Islam. Jakrta: PT Raja Grafindo, hal 37. 
otomatis menggunakan bahasa Arab. Pada masa ini, geliat keilmuan juga mulai Nampak di dunia Islam.

Oleh karena itu, sangat pantas apabila kemudian Umar berpendapat bahwa mempelajari bahasa Arab merupakan suatu keharusan. Karena saat mempalajari bahasa Arab, seseorang tidak akaan terlepas dari belajar Al Qur'an. Baik mempelajari dari segi tata bahasanya, rima atau qafiyabnya, terlebih makna yang terkandung di dalamnya, yang kesemua itu akan memberikan efek religius bagi pembacanya. Semakin banyak orang yang ahli dalam bahasa Arab, semakin mudah Islam dipahami di negara-negara yang telah berhasil ditaklukkan.

\section{b. Imam Syafi'i}

Iman Syafi'i adalah ulama besar yang dimiliki umat muslim yang tekenal sebagai ahli fiqih dan terkenal dengan mazhab Syafi'i nya. Selain itu, beliau juga dikenal sebagai ahli hadis dan juga ahli bahasa. Sebagai seorang ahli bahasa Arab, Syafi'i melahirkan berbagai karya sastra yang salah satunya dikenal dengan Diwan Imam As Syafi'i. Lantas, sebagai ahli yang telah banyak mempelajari seluk beluk bahasa Arab, bagaimana pendapat beliau tentang keistimewaan bahasa Arab?

Dalam berbagai literatur, banyak disebutkan pendapat-pendapat beliau tentang bahasa Arab, diantaranya:

$$
\text { لسان العرب أوسع الألسنة مذهبا، وأكثرها ألفاظا، ولا نعلم أن يجيط بجميع علمه إنسان غير نبي } 13
$$

"Bahasa orang Arab adalah bahasa yang terluas teorinya, terbanyak kosakatanya, dan kita tidak akan mengetahui orang selain Nabi yang memelihara kualitas bahasa Arab tersebut dengan seluruh ilmunya".

Dalam pendapat yang lain Imam Syafi'i juga menyebutkan bahwa:

$$
\text { إن الله فرض على جميع الأمم تعلم اللسان العربي بالتتبع لمخاطبتهم بالقرآن والتعبد له }
$$

"Sesungguhnya Allah mewajibkan atas seluruh umatnya untuk mempelajari bahasa Arab dengan disertai pembahasan tentang Al Qur'an dan beribadah kepadaNya"

Dari kedua pendapat Imam Syafi'i tersebut dapat disimpulkan bahwa, beliau melihat keutamaan bahasa Arab dari dua sisi, yaitu sisi lingustik dan sisi teologis. Ditinjau dari segi linguistiknya, bahasa Arab merupakan bahasa yang kaya akan tatabahasa dan kosakata. Kita lihat misalnya: untuk menyebut maf'ul (objek kalimat), bahasa Arab mempunyai setidaknya 5 jenis, yaitu: maf'ul bibi, maf'ul mutlaq, maf'ul ma'abu, maf'ul fibi, dan maf'ul min ajlih.

Sedangkan dari segi kosakata, bahasa Arab mempunyai 14 kata ganti كتب yang kesemuanya berpengaruh dalam setiap penggunaan katanya, misal: kata

13. Awadh, Ahmad Abduhu. Op.cit. hal 77.

Program Studi Pendidikan Bahasa Arab Universitas Yudharta Pasuruan https://jurnal.yudharta.ac.id/v2/index.php/studi-arab 
hanya boleh digunakan untuk kata ganti orang ketiga tunggal laki-laki (هو), untuk kata ganti yang lain, kata كتب akan berubah menyesuaikan kata ganti orang yang dimaksud.

Dari segi akar kata, kata-kata dalam bahasa Arab umunya mempunyai dasar tiga huruf konsonan. Dari ketiga huruf tersebut dapat dibentuk menjadi 6 bentuk kata yang kesemuanya mempunyai makna. Perbedaan bunyi kata akan menyebabkan perbedaan arti. Keunikan bahasa Arab juga terlihat dalam bilangan (mufrad, muthanna, dan jama'), gender (mudhakkar dan mu'annath) dan lain sebagainya ${ }^{14}$.

Sebagai ulama ahli hadis dan fiqih, tentu saja Imam Syafi'i juga menyertakan pendapatnya tentang keistimewaan bahasa Arab sebagai bahasa Al Qur'an dan Hadis. Ketika seseorang mempelajari bahasa Arab, pasti tidak akan terlepas dari mempelajari Al Qur'an. Dalam pandangan beliau, bahasa Arab yang juga merupakan bahasa kitab suci, mempunyai nilai lebih dibandingkan bahasa lain ketika dipelajari. Nilai lebih ini yang disebut sebagai pahala, karena ketika seseorang membaca Al Qur'an akan mendapat pahala, apalagi mempelajarinya.

Ulama madzhab Hanafi menguatkan pendapat Imam Syafi'i tentang nilai teologis yang terkandung ketika seseorang mempelajari bahasa Arab dalam pandangannya berikut:

$$
\text { للعبية فضل على سائر الألسن، وهو لسان أهل الجنة من تعلمها أو علمها غيره فهو مأجور }
$$

"Bahasa Arab mempunyai keutamaan atas semua bahasa, yaitu sebagai bahasa ahli surge, barangsiapa yang mempelajarinya atau mengajarkannya kepada orang lain akan mendapatkan pahala".

\section{c. Al Jahiz}

Al Jahiz adalah sastrawan terkemuka pada masa Dualah Abbasiyah. Beliau adalah orang pertama yang mengembangkan sastra Arab dalam pengertian sempit, yaitu adab (belles-letters). Al Jahiz juga merupakan guru para sastrawan Baghdad ${ }^{15}$. Pandangannya tentang bahasa Arab didasari pada pendekatan sejarah bahasa (sinkronik-diakronik). Setidaknya ada 3 pokok pendapat Al Jahiz tentang bahasa Arab, yaitu:

1. Dari segi akar sejarahnya, bahasa Arab tidak terpisahkan dengan ujaran nabi Ismail. Nabi Ismail adalah orang yang fasih berbahasa Arab,

14. Machmudah, Umi. 2005. Pembelajaran Bahasa Arab "Maudlu’I Qur-any" dengan Cooperative Learning: STAD “Student Team Achievement Division” (Pembelajaran Keterampilan Bahasa Arab Melalui Pembelajaran Al Qur'an). Jurnal El Jadid. Vol 3. No.2.2005. Prorgam Pascasarjana UIN Malang, hal.140.

15. Hitti, Philip K. 2005. History of The Arabs. Jakarta: Serambi. Hal. 504. 
padahal ia dibesarkan pada lingkungan bahasa yang lain. Sehingga membuat bahasa ibunya menjadi bahasa yang asing baginya.

2. Sebagaimana diketahui bahwa ketika Allah mengubah lisan Ismail untuk mengucapkan bahasa Arab tanpa kegagapan, tidak hanya merubah bentuk lisan secara fisiologis saja, namun juga secara watak. Kemudian menggabungkan keduanya menjadi paduan akhlak Ismail yang terpuji dan lisan yang fasih.

3. Orang Arab mempunyai tuturan yang darinya bahasa Arab menjadi berkembang, kaya kosakata, makna katanya jelas, serta gaya bahasanya sangat kaya ${ }^{16}$.

Sebagai seorang sastrawan yang sangat terkemuka di zamannya, Al Jahiz dikenal sebagai orang yang piawai dalam membuat syair-syair Arab. Spesialisali kelimuwannya adalah ilmu pengetahuan tentang ilmu sastra Arab terutama puisi, filologi Arab, sejarah bangsa Arab dan bangsa persia sebelum Islam. Selain itu ia mempelajari ilmu Alquran dan hadits. Selain itu Al Jahiz juga membaca buku-buku yang diterjemahkan dari bangsa Yunani seperti filsafat Yunani khususnya Aristoteles. Pada masa tersebut kekhilafahan Abbasiyah dalam masa keemasan dengan adanya perkembangan budaya, ilmu pengetahuan dan pendidikan. Buku-buku, perpustakaan mudah ditemukan di wilayah kekhilafahan yang memudahkan para pelajar mempelajari berbagai ilmu pengetahuan ${ }^{17}$.

Latar belakang keilmuan inilah yang kemudian melahirkan pandangannya tentang bahasa Arab ditinjau dari segi historisnya. Perkenalannya dengan bahasa lain selain Arab, membuat Al Jahiz semakin memahami betapa kayanya kosakata, tatabahasa dan gaya bahasa bahasa Arab.

\section{d. Ibnu Jinni}

Keistimewaan bahasa Arab menurut Ibnu Jinni setidaknya tertuang dalam beberapa pokok pikiran di bawah ini:

1. Ditinjau dari sumbernya, bahasa Arab merupakan bahasa yang bersumber pada Al Qur'an. Menurut Jinni, bahasa Arab adalah wahyu Allah. Hal inilah yang membuat bahasa Arab menjadi bahasa yang mulia.

2. Bahasa Arab mempunyai kaitan yang erat dengan Al Qur'an sehingga mempelajari bahasa Arab menjadi suatu hal yang sangat penting karena mempelajari bahasa Arab sama dengan mempelajari $\mathrm{Al}$ Qur'an ${ }^{18}$.

16. Awadh, Ahmad Abduhu. Op.cit. hal 79.

${ }^{17} \cdot$ http://id.wikipedia.org/wiki/Al Jahiz diakses pada Senin, 27 Oktober 2014

18. Awadh, Ahmad Abduhu. Op.cit. hal 80-81. 
Pandangan Jinni tersebut dilatarbelakangi motif teologis yang sangat kuat karena meskipun beliau adalah seorang linguis, beliau merupakan ahli bahasa yang menggabungkan linguistik dengan ushul fiqh dan ilmu kalam.

\section{e. Ath-Tha'alaby}

Pendapat Abu Mansur Ath-Tha'alaby tentang keistimewaan bahasa Arab dan keutamaan mempelajarinya adalah sebagai berikut:

1. Mempelajari bahasa Arab mempunyai kaitan erat dengan mencintai Tuhan (Allah).

2. Pembelajar bahasa Arab akan mempunyai komitmen untuk menjaganya.

3. Ada kaitan erat antara bahasa Arab dengan keimanan. Dengan keyakinan bahwa bangsa Arab adalah sebaik-baik umat dan bahasa Arab adalah sebaik-baik bahasa.

4. Mempelajari bahasa Arab adalah kunci untuk menjadi faqib agama.

5. Perkataan Abu Mansur Ath Tha'alaby:

$$
\text { يحب الأدب ويتعصب للعربية } 19
$$

"orang yang mencintai sastra pasti akan fanatik terhadap bahasa Arab".

Fanatik disini tidak dalam konotasi negatif. Tidak juga mengarah pada fanatisme kebahasaan (bahasa Arab), akan tetapi fanatisme yang dilandasi oleh motif agama yang menganjurkan mempelajari Al Qur'an yang berbahasa Arab.

Jika diteliti, pendapat Ath Tha'laby ini juga hampir sama dengan pendapat-pendapat sebelumnya yang mengatakan bahwa keawajiban mempelajari bahasa Arab tidak bisa dipisahkan dari mempelajari Al Qur'an. Pendapat yang paling menarik adalah yang mengatakan bahwa bangsa Arab adalah sebaik-baik umat dan sebaik-baik bahasa adalah bahasa Arab. Hal ini dikarenakan Al Qur'an yang diturunkan kepada seorang nabi yang bertutur Arab. Sehingga dengan kelebihan bahasa Arab adalah bahasa Al Qur'an ini digunakan sebagai penguat bahwa bahasa Arab adalah bahasa teristimewa di muka bumi juga dengan pemiliknya yaitu bangsa Arab.

\section{f. Qalqasyandy}

Al Qalqasyandy lebih dikenal sebagai seorang ahli matematika dari Mesir, ia hidup pada zaman dinasti Mamluk. Akan tetapi, ia juga mempunyai peran sebagai ahli bahasa. Diantara pendapatnya tentang bahasa Arab adalah sebagai berikut:

1. Bahasa Arab adalah bahasa yang kuat, lebih lengkap penjelasannya, dan lebih banyak kosakatanya, hal ini disebabkan semenjak awal kemunculannya, bahasa Arab memang telah diberi keistimewaan oleh

19. Ibid, hal.82-83.

Program Studi Pendidikan Bahasa Arab Universitas Yudharta Pasuruan https://jurnal.yudharta.ac.id/v2/index.php/studi-arab 
Allah dengan memilih nabi yang berbahasa Arab sebagai penerima wahyu (Al Qur'an).

2. Kekhususan bahasa Arab ada pada huruf-huruf yang lengkap, kosakata yang beragam tidak ada tambahan dan pengurangan, kosakatanya ringkas yang tidak ditemui pada bahasa-bahasa yang lain. Pendapat ini merujuk pada pada pendapat Al Fara' yang menyaatakan bahwa: "saya menemukan keistimewaan pada bahasa Arab yaitu bahwa bahasa Arab adalah bahasa seluruh umat yang dimuliakan oleh Allah, selain itu, bahasa Arab juga mempunyai ungkapan-ungkapan yang tidak dimiliki oleh bahasa lain"20.

Pendapat Al Qalqasayandy ini banyak menggali masalah yang berhubungan dengan bahasa sebagai sebuah sistem berupa lambang-lambang bunyi arbitrer yang dimiliki oleh bahasa Arab. Bahasa Arab mempunyai kosakata yang sangat kaya. Bahkan, perbedaan bunyi kata saja akan menyebabkan perbedaan arti, misalnya kalimat:

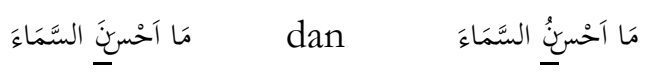

Kedua kalimat di atas sekilas sama, akan tetapi dengan perbedaan pada harakat (dlammah dan fathah) pada huruf nun menyebabkan keduanya mempunyai perbedaan makna: kalimat pertama (dlammah nun) berarti apa yang terindah di langit?. Sedangakan kalimat kedua (fathah nun) berarti betapa indahnya langit itu $^{21}$.

\section{g. Para Leksikolog}

Para leksikolog juga menemukan banyak keistimewaan bahasa Arab, diantara yang mengungkapkannya adalah;

3. Ibnu Manzur pengarang Kamus Lisan al 'Arab

Dalam mukadimah kamusnya, Ibnu Manzur menuliskan bahwa bahasa Arab adalah bahasa yang mulia, karena Al Qur'an diturunkan dalam bahasa Arab dan bahasa Arab juga menjadi bahasa ahli surga. Beliau juga mengutip hadis Nabi yang diriwayatkan dari Ibnu Abbas ra: Rasulullah SAW bersabda: Saya mencintai Arab karena tiga hal; karena saya orang Arab, Qur'an berbahasa Arab dan perkataan ahli surga adalah Arab ${ }^{22}$.

4. Syeikh Nasr al Huraini dalam mukadimah Kamus Al Muhit\}

Al Huraini berpendapat bahwa memahami kosakata bahasa adalah setengah dari memahami ilmu. Dengan memahami bahasa Arab, seseorang akan memahami makna kosakata dalam Al Qur'an dan Hadis.

20. Ibid, hal. 83-84.

21 Umi Machmudah, Op.cit. hal 142.

22 .Awadh, Ahmad Abduhu. Op.cit. 67. 
Al Huraini juga mengutip pendapat para ulama yang menyebutkan bahwa menjaga bahasa itu sama wajibnya dengan menjaga shalat, dan agama tidak akan terjaga kecuali dengan mempelajari bahasa (Arab) ${ }^{23}$.

5. Fairuzzabadi pengarang Kamus Al Muhit\}

Ilmu bahasa adalah pembuka rahasia-rahasia ilmu pengetahuan, begitu juga dalam memahami syariat yang sumbernya berbahasa Arab. Para ulama terdahulu sangat bersungguh-sungguh dalam mempelajari dan mengajarkan bahasa. Mereka tidak hanya ingin mengetahui ilmu bahasa itu saja tetapi juga ingin mencari pengaruh dari mempelajarinya ${ }^{24}$.

6. Imam Hisyam Al Ansari pengarang kitab Mughni Labib Mempelajari bahasa Arab, khususnya ilmu nahwu membantu memudahkan pembelajar untuk mencari solusi atas permasalahanpermasalahan agama dan ilmu pengetahuan lain karena sumber ilmu pengetahuan (Al Qur'an) berbahasa Arab ${ }^{25}$.

Dari beberapa pendapat di atas, dapat disimpulkan bahwa:

1. Bahasa Arab adalah bahasa dengan objek kajian terluas, mulia dan utama, mempunyai turunan terbanyak dan paling jelas maknanya.

2. Kemuliaan bahasa Arab sudah menjadi kehendak Allah, dengan diturunkannya Al Qur'an kepada Nabi Muhammad.

3. Bahasa merupakan kunci ilmu pengetahuan. Kaidah-kaidah ilmu baik sains maupun agama hanya bias dipahami dengan bahasa. Dengan demikian ilmu bahasa adalah pembuka rahasia seluruh ilmu.

4. Kaidah syariat islam adalah bahasa Arab, oleh karena itu, para ulama terdahulu bersungguh-sungguh dalam memahami ilmu bahasa Arab dan mengajarkannya serta mengungkapkan keindahan bahasa Arab.

5. Al Qur'an dan Hadis akan lebih mudah dipahami dengan bahasa Arab. Dengan demikian pengusaan bahasa yang baik sangat diperlukan guna mendapatkan hakikat kebenaran ilmu agama dan ilmu sains. Dan ilmu nahwu adalah salah satu cabang ilmu bhasa Arab yang sangat membantu untuk memahami bahasa $\mathrm{Arab}^{26}$.

h. Kutipan Pendapat Beberapa Imam

Kutipan pendapat tenang keistimewaan bahasa Arab oleh para ulama/imam ini didapat dari kitab-kitab turats:

\footnotetext{
23 . Ibid, hal. 87.

24. Ibid, hal 87-88.

25 .Ibid. hal 88-89.

26 Ibid
} 
1. Ibnu Qutaibah dalam kitab Ta'wil Musykil al Qur'an

"Keutamaan Al Qur'an bisa dipelajari dari berbagai sudut pandang, salah satunya bahasa. Bahasa Arab sebagai bahasa Al Qur'an mempunyai kekhasan dibanding bahasa lain. Keluasan Al Qur'an hanya bisa dipahami dengan bahasa Arab ${ }^{27, "}$.

2. Al Farabi dalam kitab Diwan al Adab.

"Bahasa adalah perkataan "tetangga" Allah di surga, yaitu bersih dari segala cela, dan luhur atas segala kehinaan",28.

3. Abu Husain Ahmad bin Faris dalam kitab As Sahabiy

"Sesungguhnya bahasa Arab adalah bahasa yang istimewa, kekhasannya terletak pada i'rab (gramatika), sya'ir dan 'arud',29.

4. Abu Usman As Sarqatiy

"Kemuliaan setelah Al Qur'an adalah bahasa Arab dan sastranya, pilihan hukumnya, sehingga Allah menjadikannya bahasa Al Qur'an dan bahas ahli surga. Bahasa Arab adalah bahasa yang paling fasih pengucapannya, paling jelas deskripsinya, paling kuat teorinya, paling indah dengan keindahan karya-karyanya, dan paling banyak pemakainya"30.

\section{Tanggapan terhadap Pandangan Para Ahli}

\section{a. Bahasa Arab dan Islam}

Dari berbagai pendapat tentang keutamaan bahasa Arab di atas, dapat dipahami bahwa keutamaan bahasa Arab hanya ditujukan kepada penutur muslim. Hal ini memang tidak bisa dipungkiri karena mayoritas penutur bahasa Arab adalah muslim., sehingga tidak bisa dilepaskan dari Islam. Memposisikan bahasa Arab dengan Islam, hal ini sebagaimana telah diungkapkan oleh para ulama di atas, bahwa bahasa Arab adalah kunci untuk mengungkap rahasiarahasia pengetahuan dalam Al Qur'an dan Hadis. Karena, Al Qur'an diturunkan dalam bahasa Arab, maka untuk memahaminya diperlukan pemahaman tentang kaidah-kaidah serta gaya bahasa bahasa Arab.

Bukan suatu kebetulan Al Qur'an diturunkan dalam bahasa Arab. Wahyu yang diturunkan kepada nabi terakhir dan dijadikan sebagai penyempurna agama Allah haruslah disampaikan ke dalam masyarakat yang mempunyai perbendaharaan kata yang tepat dalam mentransfer "bahasa-bahasa" Allah.

\footnotetext{
27 .Ibid. hal 90.

28 . Ibid

29 . Ibid.

30.Ibid
}

Program Studi Pendidikan Bahasa Arab Universitas Yudharta Pasuruan https://jurnal.yudharta.ac.id/v2/index.php/studi-arab 
Bahasa Arab-lah yang mempunyai prasyarat tersebut, kosakata yang berhubungan dengan filsafat, iman, hukum, social kemasyarakatan, sejarah, politik dan lain sebagainya terwakili dengan tepat. Ketepatan dan batasan makna beberapa kosakata membuatnya tidak bisa diartikan atau ditafsirkan lain, tetapi sebaliknya, ada beberapa kosakata yang bisa ditafsirkan ke dalam pengertian yang luas tergantung konteksnya. Inilah yang menjadi permasalahan jika para penerjemah Al Qur'an tidak pandai dalam lingusitik Arab ${ }^{31}$.

Misalnya, kata jannah di dalam Al Qur'an secara harfiah kata ini diterjemahkan sebagai surga. Kata surga secara harfiah juga dimiliki oleh umat Hindu yaitu svarga, tetapi secara konseptual keduanya tidak mempunyai makna yang sama. Dalam konsep svarga Hindu, penghuni surga dapat memuaskan nafsunya (seksual) dengan bidadari atau bidadara. Akan tetapi dalam Islam, para penghuni jannah atau surga adalah orang-orang yang telah mencapai kesempurnaan secara rohani, nafsunya juga telah mutmainnah (tenang-damai, tak memerlukan hubungan seksual) ${ }^{32}$.

Dalam hal ini pengetahuan tentang bahasa Arab secara kaffah memang sangat diperlukan agar transfer pengetahuan terlaksana dengan baik. Apabila hanya diterjemahkan secara harfiah, maka masyarakat awam akan terus menganggap bahwa konsep surga itu juga sama dengan svarga.

\section{b. Bahasa Arab di Luar Islam}

Apabila pendapat para ahli bahasa di atas cenderung mengungkapkan keutamaan bahasa Arab ditinjau dari motif agama, kemudian bagaimana bahasa Arab ditinjau dari segi linguistik secara umum?. Apa saja kelebihan-kelebihan bahasa Arab dibandingkan bahasa lain.

Telah diketahui bahwa dalam bahasa Arab ada berbagai macam kaidah, diantaranya; gender (muannats/feminine dan mudhakkar/maskulin), bilangan (mufrad, mutsanna, jamak), tenses/waktu (madi, mudari), kalimat (ismiyyah dan fi'liyyah), 'arud dan qafiyah dan masih banyak lagi, hal ini merupakan kaidah bahasa yang kompleks. Bahasa Inggris juga mengenal dua gender akan tetapi dalam bilangan tidak mengenal mutsanna (dual), bahasa Jerman membagi gendernya menjadi 3 (maskulin, feminin dan netral), juga mempunyai kata ganti yang jumlahnya hamper sama dengan bahasa Arab (13 kata ganti), tetapi tidak mengenal bentuk bilangan yang sama dengan bahasa Arab. Hal inilah yang menjadikan bahasa Arab menjadi bahasa yang istimewa disbanding bahasabahasa lain.

31. Arsyad, Azhar. Op.cit. hal.8

32 Ibid, hal 9.

Program Studi Pendidikan Bahasa Arab Universitas Yudharta Pasuruan https://jurnal.yudharta.ac.id/v2/index.php/studi-arab 
Dengan demikian, bagi orang diluar Arab dan non-muslim, ketika mempelajari bahasa Arab akan menemukan kesulitan-kesulitan yang lebih dibanding ketika mempelajari bahasa lain. Namun, keunikan bahasa Arab yang "sulit" ini rupanya yang menarik perhatian para peneliti di luar negara Arab juga Islam. Banyak pusat studi Arab yang dibuka diberbagai universitas terkemuka di dunia, misalnya jurusan bahasa Arab di universitas Leipzig, Jerman, jurusan bahasa Arab dan Studi Islam di universitas Georgetown, Washington DC. Hal ini menunjukkan bahwa bahasa Arab tidak lagi hanya milik orang Islam. Kebutuhan akan bahasa Arab tidak lagi berlandaskan motif agama saja tetapi lebih dari itu, bahasa sebagai komunikasi global merupakan orientasi belajar bahasa asing di era modern ini.

Setidaknya ada beberapa alasan mengapa orang asing (non-muslim) mempelajari bahasa Arab. Salah satunya adalah bahasa Arab adalah bahasa yang tidak biasa. Semenjak kasus 9/11, bangsa Arab menjadi momok bagi dunia Barat, begitu juga dengan budayanya, apalagi mempelajari hal-hal yang berhubungan dengan Arab. Apabila orang non-muslim mempelajari bahasa Arab, ketegangan akan tercairkan dengan terbukanya pintu dialog antara Muslim-Barat. Sehingga apabila komunikasi terbangun dengan baik, maka kerjasama juga akan terjalin dengan baik pula.

Alasan berikutnya adalah bahwa huruf Arab berbeda dengan huruf Latin, hal ini juga menjadi daya tarik tersendiri dalam mempelajari bahasa Arab. Alasan ketiga, bahasa Arab mempunyai kosakata yang bisa berkembang. Satu kata bisa dikembangkan menjadi lebih dari 30 turunan kata yang berbeda artinya. Hal ini yang tidak bisa ditemukan pada bahasa lain selain Arab. Kesemua inilah yang menjadikan bahasa Arab menjadi objek kajian yang menarik untuk dipelajari di zaman sekarang.

\section{Penutup}

Allah menurunkan Al Qur'an ke dalam bahasa Arab bukan karena kebetulan belaka. Semenjak zaman Ismail, Allah telah menyiapkan bahasa Arab sebagai bahasa untuk menerjemahkan ilmunya kepada umat manusia. Keistimewaan-keistimewaan bahasa Arab yang telah juga dipersiapkan oleh Allah menjadikan bahasa Arab menjadi bahasa yang tidak pernah habis objek kajiannya. Sebagai seorang muslim, mempelajari bahasa Arab sama wajibnya dengan shalat, karena bahasa Arab mempunyai kaitan yang kuat dengan Al Qur'an dan hadis. Hal inilah yang membuat para ulama dahulu membuat deskripsi tentang keistimewaan bahasa Arab dan mempelajarinya dengan 
menyandingkannya dengan keistimewaan Al Qur'an dan faedah dari mempelajarinya.

Dalam konteks yang lebih luas, mengesampingkan motif agama dari pembelajaran bahasa Arab, secara structural, bahasa Arab mempunyai susunan yang kompleks, mulai dari tingkat hingga kata gaya bahasa semuanya menunjukkan cirri khas yang sangat indah, menarik dan menjadikannya bahasa yang luhur dan mulia, selain ia sendiri adalah bahasa Al Qur'an. Belajar dan mengajarkan bahasa Arab adalah fardhu kifayah sebagaimana pendapat Ibnu Taimiyah.

Terlepas dari pendapat-pendapat para ulama klasik tentang keutamaan bahasa Arab yang hamper seluruhnya mengaitkan pada motif agama, bahasa Arab sebagai bahasa bangsa Arab memang memiliki banyak kelebihan di bandingkan dengan bahasa-bahasa lain di dunia. Bahasa Arab mempunyai kosakata yang sangat kaya, misalnya; penyebutan kata ganti yang berjumlah 14 yang kemudian berpengaruh pada setiap kata yang mengikuti kata ganti tersebut baik subjek, predikat maupun objeknya. Meskipun ciri seperti ini juga ada dalam bahasa Jerman yang juga mengenal pembagian kata ganti yang berjumlah 8 dengan 3 pembagian gender (feminine, maskulin dan neutral). Gaya bahasa bahasa Arab juga beragam terutama digunakan dalam syair. Namun, secara struktur, bahasa Arab masih sama dengan bahasa-bahasa lain di dunia. 


\section{Daftar Pustaka}

Amin, Usman. 1965. Falsafah al Lugah al Arabiyyah. Kairo: Dar al Masriyah li Ta'lif wa Tarjamah.

Amstrong, Karen. 2003. Islam Sejarah Singkat. Yogyakarta: Penerbit Jendela.

Arsyad, Azhar. 2010. Bahasa Arab dan Metode Pengajarannya; Beberrapa Pokok Pikiran. Yogyakarta:Pustaka Pelajar.

Awadh, Ahmad Abduhu. 2000. Fi Fadlli al Lugah al Arabiyyah, ta'liman wa tabditsan wa iltizaman. Kairo: Markaza al Kitab li an Nasyr.

Ghazzawi, Sabah. 1992. The Arabic Language. Washington D.C:Center for Contemporary Arab Studies.

Hermawan, Acep. 2011. Metodologi Pembelajaran Bahasa Arab. Bandung: PT. Remaja Rosdakarya.

Hitti, Philip K. 2005. History of The Arabs. Jakarta: Serambi.

Al-Khuli, Muhammad Ali.1982. Asalib Tadris al Lugah al 'Arabiyyah. Riyadh: Mamlakah al 'Arabiyyah as Su'udiyyah.

Machmudah, Umi. 2005. Pembelajaran Bahasa Arab "Maudlu'I Qur-any" dengan Cooperative Learning: STAD "Student Team Achievement Division" (Pembelajaran Keterampilan Bahasa Arab Melalui Pembelajaran Al Qur'an). Jurnal El Jadid. Vol 3. No.2.2005. Prorgam Pascasarjana UIN Malang.

Al Yasiri, Ali Mazhar. 2003. Al Fiker an Nabwi Inda al 'Arab Usulubu wa Manabijubu. Beirut: Dar al 'Arabiyyah Lil Mausu'ah.

Yatim, Badri. 1993. Sejarab Peradaban Islam. Jakrta: PT Raja Grafindo. http://id.wikipedia.org/wiki/Al_Jahiz diakses pada Senin, 27 Oktober 2014 
116 | Volume 10, Nomor 2, Desember 2019

Program Studi Pendidikan Bahasa Arab Universitas Yudharta Pasuruan https://jurnal.yudharta.ac.id/v2/index.php/studi-arab 